(C) 2012

Шкурко В. С., здобувач*

Полтавська державна аграрна академія

\title{
ВПЛИВ ПОГОДНИХ УМОВ, ПОПЕРЕДНИКІВ І ДОБРИВ НА ВРОЖАЙНІСТЬ СОРТІВ ЯЧМЕНЮ ПИВОВАРНОГО
}

\section{Рецензент - кандидат сільськогосподарських наук М. І. Кулик}

\begin{abstract}
У ході чотирирічних досліджень встановлено, щзо найбільший вплив на формування врожайності ячменю пивоварного проявляють умови років виромування. Серед регульованих факторів найбільше значення мають добрива. Забезпечення рослин ячменю добривами в нормі $N_{30} P_{30} K_{30}$ дає значне збільшення врожайності незалежно від попередника. Сортові властивості також мають істотний вплив. Встановлена істотна взаємодія попередників і сортових властивостей, попередників і удобрення, сортів $i$ удобрення, величина впливу яких залежить від умов вирощування. Застосування добрив дає змогу підвищити врожайність ячменю на 0,89-1,06 m/2а, а використання добрива Нутривант Плюс пивоварний ячмінь призводить до дещо меншого зростання врожайності-0,58-0,61 m/2а. Правильний добір сорту для вирощування може принести додатково ще 0,26-0,37 m/2a.
\end{abstract}

Ключові слова: ячмінь пивоварний, сорт, удобрення, попередник, урожайність.

Постановка проблеми. Виробництво високоякісного пивоварного зерна вимагає значно досконалішого підходу до вирощування ячменю, ніж на продовольчі або фуражні цілі. Головними аспектами у цьому є правильний підбір сортів для вирощування, досконало розроблена система удобрення культури, детальний аналіз впливу умов вирощування на формування врожайності 3 метою подальшого управління нею. Поскільки сучасний стан української пивоварної промисловості вимагає значної кількості високоякісної сировини, то проблема забезпечення нею вітчизняних пивоварів стоїть наразі надзвичайно гостро.

Аналіз основних досліджень і публікацій, у яких започатковано вирішення проблеми. Добрива наразі $є$ одним із тих найважливіших факторів, що дозволяють ефективно управляти врожайністю й якістю зерна. Для ячменю пивоварного цей аспект особливо важливий, оскільки дана культура, ефективно реагуючи на застосування добрив, не лише збільшує врожайність, а й здатна істотно накопичувати вміст білку в зерні. Остатнє є досить гострою проблемою для пивоварів.

Урожайність від застосування добрив на всіх типах грунтів зростає завдяки збільшенню значень таких ознак, як кількість колосків на одиниці площі, маси 1000 зерен, маси зерен з одного колоса та натури [1]. Актуальними залишаються і питання строків внесення добрив, їх впливу на зміну взаємозв' язків між продуктивністю рослин та якістю зерна [2].

Надзвичайно важливим для ячменю пивоварного $є$ й вибір попередника, до кращих з яких відносять буряки цукрові та кукурудзу на зерно [3]. Остання заслуговує особливої уваги, поскільки площі під нею зростають. Однак кукурудзу називають небажаним попередником через те, що насіння ячменю в такому разі проростає повільніше. В зв'язку з цим вважається, що буряки цукрові $\epsilon$ кращим попередником, проте деякі автори наголошують на тому, що запаси продуктивної вологи та поживних речовин після кукурудзи більші [4-6]. Таким чином, це питання залишається досить дискусійним.

Для отримання високоякісного пивоварного ячменю необхідно добирати лише спеціальні сорти, поскільки лише ця умова здатна задовольнити вимоги щодо основних показників якості, однорідності й вирівняності насіння, відповідності сортових властивостей умовам вирощування. Останнім часом на ринку України переважають інтенсивні сорти, добираючи які можна істотно збільшити врожайність, однак вони вимагають ретельного підходу до технології вирощування [7].

Метою досліджень було встановлення параметрів мінливості врожайності під дією умов вирощування років проведення експерименту, реакцію сортів різного походження на удобрення, визначення оптимального варіанту підбору сортів і технології їх живлення.

\footnotetext{
* Керівник-доктор сільськогосподарських наук, професор Г. П. Жемела
} 


\section{СТОРІНКА МОЛОДОГО ВЧЕНОГО}

Матеріал та методи досліджень. Матеріалом для досліджень стали 10 сортів ячменю пивоварного напряму використання, що висівалися після двох попередників (буряки цукрові та кукурудза на зерно) на трьох фонах живлення: без добрив, внесення нітроамофоски $\left(\mathrm{N}_{30} \mathrm{P}_{30} \mathrm{~K}_{30}\right)$ і застосування добрива Нутривант Плюс пивоварний ячмінь $\left(\mathrm{ON}-23 \mathrm{P}_{2} \mathrm{O}_{5}-42 \mathrm{~K}_{2} \mathrm{O}+0,1 \mathrm{~B}+0,5 \mathrm{Zn}+\right.$ Фертівант (ФВ) у дозі 3 кг/га. Статистичну обробку результатів експерименту проводили за допомогою програми STATISTICA 6.0.

Результати досліджень. Дослідження проводилися протягом 2008-2011 рр., які характеризувалися досить значною відмінністю погоднокліматичних умов, що позначилося на врожайності ячменю. Так, у 2008 році врожайність досліджуваних сортів знаходилася в межах 3,924,15 т/га, у 2009 році вона була майже на одну тонну нижчою (2,86-3,24 т/га). 2010 рік характеризувався аномальною температурою й досить тривалим спекотним бездощовим періодом, що спостерігався практично від часу сівби й до збирання врожаю. Відповідно, й рівень урожайності в досліді становив 2,66-2,98 т/га за середнім показником по сортах. У 2011 році умови вирощування хоча й не були оптимальними для отримання зерна пивоварної якості, проте спостерігалося істотне збільшення урожайності - 3,593,97 т/га.

Аналіз впливу умов вирощування на врожайність та ії дисперсії показує, що досліджувані сорти характеризувалися незначною мінливістю (коефіцієнтом варіації) між собою, що свідчить про їх однакову реакцію на попередники та удобрення, а найбільше варіювала врожайність під дією добрив (див. табл.) - частка впливу цього фактора серед тих, що вивчалися, була найбільшою. Другою за величиною є частка впливу сортів і лише потім - попередників. Відмічена також істотність впливу взаємодії факторів на формування врожайності ячменю.

Якщо проаналізувати результати впливу умов кожного року окремо, то закономірності виглядатимуть дещо інакше. Так, наприклад, у сприятливому році вплив на формування врожайності мали всі досліджувані фактори та взаємодія кожного з них між собою. У менш сприятливих 2009 і 2010 роках неістотною виявилася взаємодія попередників та удобрення. Детальніший аналіз показує, що погодні умови вегетації, що складаються в конкретно взятому році, мають значний вплив на характер дії й взаємодії сортових властивостей, добрив і вибору попередника.

Аналізуючи врожайність ячменю в розрізі сортів, варто зауважити, що найкращими сортами, які демонстрували високий рівень врожайності, були Джерзей, Кангу, Ксанаду, а найнижча врожайність була у сортів Престиж, Пасадена та Целінка. 3-поміж сортів української селекції кращим виявився сорт Гетьман, який, щоправда, перевищував сорт Престиж лише на 0,15 т/га при $\mathrm{HIP}_{05}=0,2$ т/га (рис. 1).

На рисунку 2 зображено варіацію урожайності під дією попередників і добрив. Після буряка цукрового середня врожайність ячменю по сортах становила 3,45 т/га, а після кукурудзи на зерно - 3,41 т/га. Хоча така різниця знаходиться в межах помилки досліду, однак, на наш погляд,

Урожайність сортів ячменю залежно від попередників та удобрення (2008-2011 рр.)

\begin{tabular}{|c|c|c|c|c|c|c|c|c|c|c|c|c|c|c|c|c|}
\hline \multirow{4}{*}{$\begin{array}{l}\text { Назва } \\
\text { сорту }\end{array}$} & \multicolumn{16}{|c|}{ Попередники } \\
\hline & \multicolumn{9}{|c|}{ цукровий буряк } & \multicolumn{7}{|c|}{ кукурудза на зерно } \\
\hline & \multicolumn{3}{|c|}{ без добрив } & \multicolumn{3}{|c|}{$\mathrm{N}_{30} \mathrm{P}_{30} \mathrm{~K}_{30}$} & \multicolumn{3}{|c|}{$\begin{array}{c}\text { Нутрівант } \\
\text { Плюс Пиво- } \\
\text { варний ячмінь }\end{array}$} & \multicolumn{3}{|c|}{ без добрив } & \multicolumn{3}{|c|}{$\mathrm{N}_{30} \mathrm{P}_{30} \mathrm{~K}_{30}$} & $\begin{array}{c}\text { Нутрівант } \\
\text { Плюс } \\
\text { Пивоварний } \\
\text { ячмінь }\end{array}$ \\
\hline & 86 & & 2,85 & & 01 & & & 8 & -1 & 52 & 2 & & & 3,84 & & \begin{tabular}{|l|l|l|}
3,19 & 3,34 & 3,31 \\
\end{tabular} \\
\hline & 02 & & 3,00 & & 94 & & & & & & & & 3,91 & 4,00 & & 3,36 \\
\hline & 05 & 94 & 3,01 & 3,60 & 4,00 & 4,05 & 3,36 & 3,35 & 3,25 & 2,65 & 2,71 & & 3,73 & 3,69 & & 3,39 \\
\hline Дж & 08 & 79 & 3,09 & 4,21 & 3,96 & 4,01 & 3,83 & 3,84 & 3,70 & 3,21 & 3,04 & 3,08 & 4,18 & 4,34 & 4,06 & $3,62 \quad 3,71$ \\
\hline & 3,16 & 08 & 3,23 & 3,93 & 3,99 & 4,04 & 3,63 & 3,80 & 3,70 & 3,07 & 3,05 & 2,92 & 3,87 & 3,91 & 3,90 & \begin{tabular}{|l|l|l|}
3,34 & 3,37 & 3,45 \\
\end{tabular} \\
\hline Скар. & 3,13 & 3,22 & 3,18 & 3,67 & 3,75 & 3,85 & 3,30 & 3,30 & 3,48 & 3,20 & 3,18 & 3,11 & 3,81 & 3,83 & 3,98 & \begin{tabular}{|l|l|l|}
3,23 & 3,28 & 3,31 \\
\end{tabular} \\
\hline & 3,20 & 05 & 3,12 & 3,78 & 3,93 & 3,93 & 3,52 & 3,51 & 3,66 & 2,77 & 2,77 & 2,58 & 3,85 & 3,82 & 3,75 & $3,24 \quad 3,41$ \\
\hline & 3,08 & 2,83 & 3,17 & 4,16 & 3,86 & 3,97 & 3,62 & 3,63 & 3,69 & 2,96 & 2,92 & 2,87 & 3,88 & 3,83 & 3,93 & \begin{tabular}{|l|l|}
3,44 & 3,48 \\
\end{tabular} \\
\hline & 79 & 2,63 & 2,85 & 3,80 & 3,66 & 3,83 & 3,69 & 3,76 & 3,70 & 2,79 & 2,65 & 2,66 & 4,08 & 4,24 & 3,53 & \begin{tabular}{|l|l|}
3,69 & 3,91
\end{tabular} \\
\hline & 2,76 & 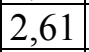 & 2,90 & 3,66 & 3,64 & 3,82 & 3,47 & 3,24 & 3,30 & 2,78 & 2,67 & 2, & 3,97 & 4,17 & 3,75 & \begin{tabular}{|l|l|l|}
3,34 & 3,69 & 3,7 \\
\end{tabular} \\
\hline גHE & 3,01 & 2,84 & 3,04 & 3,78 & 3,84 & 3,93 & 3,53 & 3,55 & 3,54 & 2,91 & 2,85 & 2,78 & 3,91 & 3,97 & 3,85 & \begin{tabular}{|l|l|l|}
3,38 & 3,50 & 3,4 \\
\end{tabular} \\
\hline
\end{tabular}


це підтверджує тезу, що кукурудза на зерно є дещо гіршим попередником, аніж буряки цукрові.

Добрива мають найістотніший вплив на врожайність ячменю. Так, у варіантах, де попередниками були буряки цукрові, застосування нітроамофоски забезпечувало зростання врожайності на 0,89 т/га, а в таких же варіантах із попередником кукурудза на зерно на 1,06 т/га.
Застосування добрива Нутрівант Плюс пивоварний ячмінь ефективне також на посівах ячменю. Так, після цукрових буряків приріст врожайності становив 0,58 т/га, а після кукурудзи на зерно - 0,68 т/га, що свідчить про значні перспективи застосування цього добрива для отримання зерна ячменю пивоварної якості, хоча для підвищення врожайності воно менш ефективне, ніж нітроамофоска.

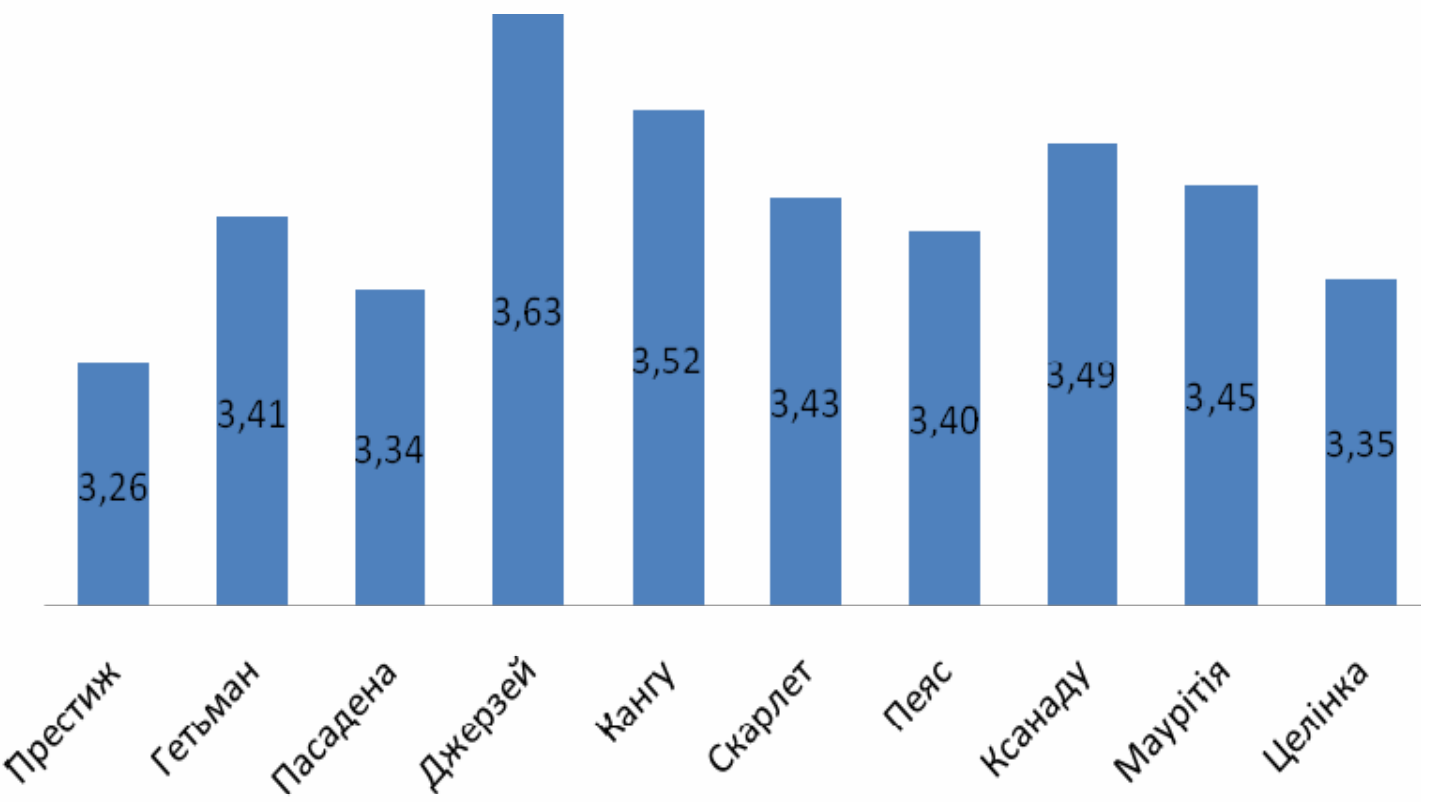

Рис. 1. Урожайність ячменю залежно від сортових властивостей, $m / 2 a$

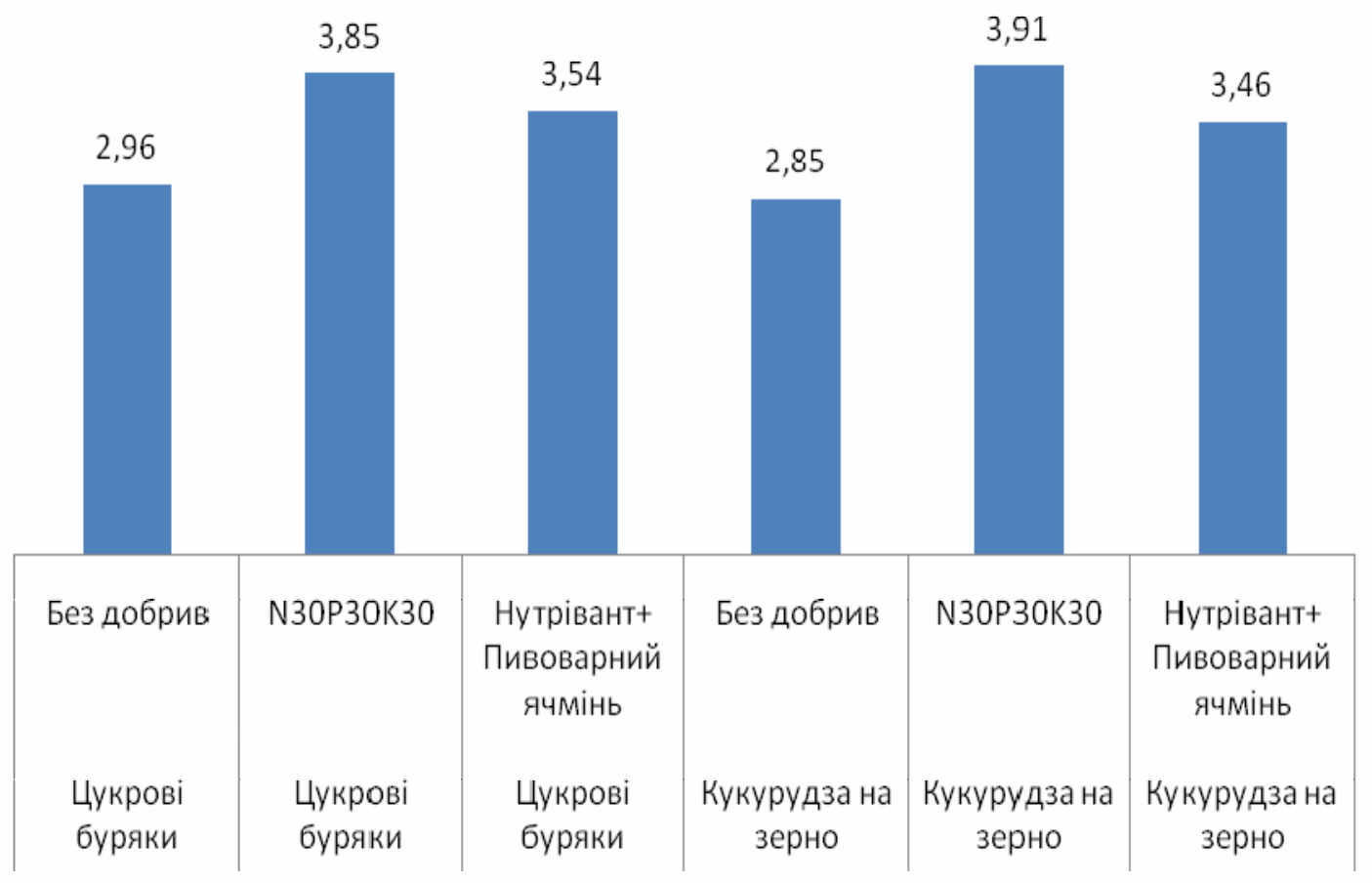

Рис. 2. Урожсайність ячменю залежно від попередників та застосування добрив, $\mathrm{m} / 2$ a 
Обробка результатів експерименту методом багатофакторного дисперсійного аналізу дала можливість встановити найкращі варіанти, що оптимально поєднують у собі дію і взаємодії всіх досліджуваних нами факторів.

Найкращимим виявилися ті варіанти, де було висіяно сорт Джерзей після кукурудзи на зерно із внесенням добрив у вигляді нітроамофоски $\left(\mathrm{N}_{30} \mathrm{P}_{30} \mathrm{~K}_{30}\right)-4,19$ т/га та цукрового буряка 4,06 т/га. Практично аналогічною була врожайність у сорту Ксанаду після цукрових буряків із тим же варіантом удобрення - 4,0 т/га. Решта варіантів мала статистично меншу врожайність, аніж у наведених вище.

Таким чином, у наших дослідженнях найголовнішу роль у формуванні врожайності ячменю відігравали добрива та вдалий підбір сорту для умов вирощування (Джерзей і Ксанаду).

Найкраще на застосування добрива Нутрівант Плюс пивоварний ячмінь реагують сорти Джерзей, Маурітія та Кангу - рівень врожайності їх досягав 3,8 т/га у середньому, що практично дорівнювало врожайності у варіантах із сортами

\section{БІБЛІОГРАФІЯ}

1. Борисоник 3. Б. Ячмень яровой / З. Б. Борисоник. - М. : Колос, 1974. -255 с.

2. Гулидова B. A. Особенности возделывания ячменя для производства солода / В. А. Гулидова // Зерновое хозяйство. - 2001. - №3. - С. $26-29$.

3. Наукове забезпечення ефективного проведення комплексу весняно-польових робіт 2007 року в господарствах Харківської області: Рекомендації. - Х., 2007. - $56 \mathrm{c.}$

4. Пабат I. А., Горобеиь А. Г., Горбатенко А. I. Попередники, добрива і обробіток грунту під ячмінь ярий у Степу // Вісник аграрної науки. -
Гетьман, Пасадена, Скарлет, Пеяс, Целінка, які удобрювали за допомогою нітроамофоски. У цілому ж можна стверджувати про більший вплив на врожайність мінеральних добрив, аніж Нутріванту у дозі, яка вивчалася.

\section{Висновки:}

На підставі проведених досліджень встановлено, що на врожайність ячменю найбільше впливають добрива та добір сортів, хоча підбір попередника також має суттєве значення, передусім для зони нестійкого зволоження. В зоні нестійкого зволоження цукрові буряки і кукурудза на зерно мають практично однакове значення як попередники для вирощування ячменю.

Кращими сортами, які можна використовувати в умовах зазначеної зони, є сорти Джерзей та Ксанаду, які найсильніше реагують на внесення добрив.

Застосування добрива Нутрівант Плюс пивоварний ячмінь $\epsilon$ теж досить ефективним, хоча й поступається за впливом мінеральним добривам на $0,3 \mathrm{~T} /$ га.

2002. - №4. - C. 17-21.

5. Петр И., Байер Я., Буреш Р., Цоуфал В. Погода и урожай / Пер. с чешского 3. К. Благовещенской. - М.: Агропромиздат, 1990. - 332 с.

6. Сівозміни при інтенсивному землеробстві: (Монографія) / С. М. Лебедь, I. І. Андрусенко, I. А. Пабат. - К.: Урожай, 1992. - 224 с.

7. Karamanos A. J., Papatheohari A.Y. Assessment of drought resistance of crop genotypes by means of the water potential index // Crop Sci. - 1999. Vol. 39. - S. 1792. 